\title{
COMMENTARY
}

\section{Enteral nutrition: better navigation, yet unknown destination?}

\author{
Michael P Casaer* and Dieter Mesotten \\ See related research by Wierdsma et al., http://ccforum.com/content/15/6/R264
}

\begin{abstract}
The nutrition dose truly absorbed by a patient is crucial information in the management or the investigation of nutrition during critical illness. In the present issue of Critical Care, assessment of nutritional losses in stools was studied. These losses together with enteral nutrition lost in gastric fluids and enteral nutrition prescribed but never infused make up the difference between the dose supposedly given to a patient and the amount effectively taken up. Additionally, the optimal dosing and timing of nutrition during critical illness are still debated. When enteral nutrition is insufficient, the options are limited.
\end{abstract}

In their article in the present issue of Critical Care, Wierdsma and colleagues validated a novel and feasible method to measure the degree to which enteral nutrition (EN) is absorbed by the gastrointestinal tract. The accuracy of simply weighing daily faecal production to identify gastrointestinal dysfunction was validated against three reference methods [1]. Energy losses in faeces were measured by laboratory-based bomb calorimetry. The contribution of protein and fat to the faecal nutritional losses were estimated by labour-intensive chemical analyses [2,3]. The authors identified a daily faecal weight above $>350 \mathrm{~g}$ as a reliable indicator for gastrointestinal malabsorption. The correlation between intestinal energy malabsorption and measured faecal weight was highly significant [1]. Of course, these results need to be confirmed in a larger study population, including the most critically ill and those with known gastrointestinal problems.

The present study is of methodological and conceptual importance to nutritional research and clinical nutrition

*Correspondence: michael.casaer@uzleuven.be

Department of Intensive Care Medicine, University Hospital Leuven, University of Leuven, B-3000 Leuven, Belgium management. First, the validation of this new assessment technique has been done in a very accurate and complete way and thereby provides a new reliable tool. Secondly, these results focus on a rarely addressed problem in the critically ill: is the EN administered to a patient truly absorbed? In 9 out of the 48 stable patients in this trial, the nutrition was only partially absorbed. This 19\% represents a high incidence of gastrointestinal dysfunction since patients with known gastrointestinal problems were not included [1]. Previous studies assessed and treated diarrhoea in critically ill patients, measuring the frequency, liquidity and volume of stools but not the proportion of EN energy, proteins and fat lost by the patient $[4,5]$.

Whether studying the effect of nutritional interventions or managing nutrition in clinical practice, we will have to take into account these data on gastrointestinal energy losses. It is also timely to remind researchers and clinicians of other confounders. The discrepancy between prescribed and effectively infused EN doses in critically ill patients is relevant. Interruptions of EN for procedures, emesis, high gastric residual volumes (GRVs), diarrhoea and feeding tube replacement are important culprits [6]. EN lost in GRVs being discarded after GRV assessment can be measured using a refractometer [7]. An alternative is to reinject GRVs after measuring or to refrain from measuring GRVs, since evidence supporting this practice is limited [8]. Briefly, we should be aware that the amount of EN effectively taken up by the patient is the prescribed volume minus the volume not administered to the patients, minus the EN discarded with GRV minus the EN lost in faeces.

Two more questions remain, however. How much EN do we want to give? And what can we do when EN does not achieve this goal?

First, how should we determine the nutritional target? Indirect calorimetry measurement of energy expenditure is an attractive individualised method. Indirect calorimetry, however, does not measure energy needs but energy consumption, and indirect calorimetry is less reliable in patients on renal replacement therapy, aggressive ventilation and other conditions often present in the 
critically ill [9]. A recent randomised trial showed more morbidity in the ICU, but an unexplained reduction in hospital mortality in the per-protocol analysis, when feeding was guided by indirect calorimetry [10]. The next issue is how fast the nutritional target should be reached. Recent trials found no benefit in early EN administration up to the calculated target as compared with low EN intake [11,12].

Finally, what should be done if EN uptake is insufficient? Probiotics or fibre-rich EN reduced the volume or frequency of diarrhoea in critically ill patients in some of the few randomised controlled trials on this topic $[4,5]$. Whether this reduction also improved gastrointestinal absorption is unknown. Absorption of EN by dysfunctional gut could be facilitated by the absence of proteins or even peptides in, respectively, semi-elemental EN or elemental EN; however, trials in critically ill patients failed to provide convincing evidence $[13,14]$. The best controlled method to effectively complete insufficient EN would be the intravenous administration of nutrition: parenteral nutrition. Supplementing insufficient EN with parenteral nutrition during the first week of critical illness, however, resulted in more infections and delayed recovery in a large randomised controlled trial [15].

In conclusion, the optimal EN dose during different stages of critical illness is not yet known. Stool weight measurements could improve our knowledge of true EN absorption, however, and could thus lead to more accurate research and clinical practice.

Abbreviations

EN, enteral nutrition; GRV, gastric residual volume.

\section{Competing interests}

KU Leuven received an institutional partial (<30\%), unconditional and nonrestrictive research grant for the EPaNIC trial from Baxter Healthcare (Maurepas, France). The authors declare that they have no competing interests.

\section{Acknowledgements}

MPC receives funding from the Research Foundation Flanders, Belgium (FWO doctoral fellowship), and DM from the Clinical Research Fund of the University Hospitals Leuven, Belgium (postdoctoral fellowship).

Published: 2 December 2011

\section{References}

1. Wierdsma NJ, Peters JHC, Weijs PJM, Keur MB, Girbes ARJ, van Bodegraven AA, Beishuizen A: Malabsorption and nutritional balance in the ICU - faecal weight as a biomarker: a prospective pilot study. Crit Care 2011, 15:R264.
2. van de Kamer JH, Pikaar NA, Bolssens-Frankena A, Couveeploeg C, Van GL: Quantitative determination of the different higher saturated fatty acids in fat from blood, chyle and faeces, by means of partition chromatography on rubber. Biochem J 1955, 61:180-186.

3. Rudman D, Millikan WJ, Richardson TJ, Bixler TJ, Stackhouse J, McGarrity WC: Elemental balances during intravenous hyperalimentation of underweight adult subjects. J Clin Invest 1975, 55:94-104.

4. FrohmaderTJ, Chaboyer WP, Robertson IK, Gowardman J: Decrease in frequency of liquid stool in enterally fed critically ill patients given the multispecies probiotic VSL\#3: a pilot trial. Am J Crit Care 2010, 19:e1-e11.

5. Spapen H, Diltoer M, Van MC, Opdenacker G, Suys E, Huyghens L: Soluble fiber reduces the incidence of diarrhea in septic patients receiving total enteral nutrition: a prospective, double-blind, randomized, and controlled trial. Clin Nutr 2001, 20:301-305.

6. O'Leary-Kelley CM, Puntillo KA, Barr J, Stotts N, Douglas MK: Nutritional adequacy in patients receiving mechanical ventilation who are fed enterally. Am J Crit Care 2005, 14:222-231.

7. Chang WK, Chao YC, Mcclave SA, Yeh MK: Validation the use of refractometer and mathematic equations to measure dietary formula contents for clinical application. Clin Nutr 2005, 24:760-767.

8. Ridley EJ, Davies AR: Practicalities of nutrition support in the intensive care unit: the usefulness of gastric residual volume and prokinetic agents with enteral nutrition. Nutrition 2011, 27:509-512.

9. Branson $\mathrm{RD}$, Johannigman JA: The measurement of energy expenditure. Nutr Clin Pract 2004, 19:622-636.

10. Singer P, Anbar R, Cohen J, Shapiro H, Shalita-Chesner M, Lev S, Grozovski E, Theilla M, Frishman S, Madar Z: The tight calorie control study (TICACOS): a prospective, randomized, controlled pilot study of nutritional support in critically ill patients. Intensive Care Med 2011, 37:601-609.

11. Rice TW, Mogan S, Hays MA, Bernard GR, Jensen GL, Wheeler AP: Randomized trial of initial trophic versus full-energy enteral nutrition in mechanically ventilated patients with acute respiratory failure. Crit Care Med 2011, 39:967-974.

12. Ibrahim EH, Mehringer L, Prentice D, Sherman G, Schaiff R, Fraser V, Kollef MH: Early versus late enteral feeding of mechanically ventilated patients: results of a clinical trial. JPEN J Parenter Enteral Nutr 2002, 26:174-181.

13. Mowatt-Larssen CA, Brown RO, Wojtysiak SL, Kudsk KA: Comparison of tolerance and nutritional outcome between a peptide and a standard enteral formula in critically ill, hypoalbuminemic patients. JPEN J Parenter Enteral Nutr 1992, 16:20-24.

14. Heimburger DC, Geels VJ, Bilbrey J, Redden DT, Keeney C: Effects of smallpeptide and whole-protein enteral feedings on serum proteins and diarrhea in critically ill patients: a randomized trial. JPEN J Parenter Enteral Nutr 1997, 21:162-167.

15. Casaer MP, Mesotten D, Hermans G, Wouters PJ, Schetz M, Meyfroidt G, Van CS, Ingels C, Meersseman P, Muller J, Vlasselaers D, Debaveye Y, Desmet L, Dubois J, Van AA, Vanderheyden S, Wilmer A, Van den Berghe G: Early versus late parenteral nutrition in critically ill adults. NEngl J Med 2011, 365:506-517.

doi:10.1186/cc10538

Cite this article as: Casaer MP, Mesotten D: Enteral nutrition: better navigation, yet unknown destination? Critical Care 2011, 15:1015. 